\title{
FAKTOR-FAKTOR PENENTU KEMENANGAN WAKIL BUPATI MELAWAN BUPATI DALAM PILKADA 2015 DI KABUPATEN BUNGO PROVINSI JAMBI
}

\author{
Oleh \\ Muhammad Ismail ${ }^{1}$, \\ Djohermansyah Djohan ${ }^{2}$, Dahyar Daraba ${ }^{3}$ \\ 1) Pemerintah Kabupaten Bungo \\ Program Magister Terapan Studi Pemerintahan Daerah Institut Pemerintahan Dalam Negeri \\ mismail.smile@yahoo.co.id \\ 2,3) Institut Pemerintahan Dalam Negeri
}

\begin{abstract}
$T$ This study aims to describe what factors determine the victory of the Deputy Regent against the Regent in the 2015 Pilkada in Bungo Regency, Jambi Province. The research was conducted through data collection through interviews and supported literature reference sources related to analyzing data findings. The method used is descriptive qualitative. In this study, researchers were directly involved in digging up information. Deductively, the author uses the theory of Peter Schroder (2010) as a knife of analysis to describe the winning factor of the Deputy Regent against the Regent in the 2015 Pilkada.

The results showed that the Deputy Regent of Bungo had a number of advantages in internal factors that could be used in the 2015 Regional Head Election to attract sympathy from voters. There are advantages of strength a). Profile of candidate pairs based on regional basis and ethnic identity, b). Religious individuals, 3). Interesting program, 4). Performance tested, 5). Competence based on education, and 5). The strength of the success team that was rooted down to the villages made the Deputy Regent win victory in the Pilkada. Then several strategies are used based on the analysis: 1. Selection of a successful team, the steps to determine the selection of a successful team include a) Pre-election approaches, b). Expanding relationships, c). Loyal character, d). Team formation to remote areas, e). Communication to the success team, 2. Logistical processing ability of Candidate Candidates to be able to use financial resources appropriately, 3. Selection of candidate and regional profiles, dissemination of voters that are not focused on just one point, and 4. Formulation of programs that attract the hearts of the public based on from problems in the field that correspond to the largest population distribution.
\end{abstract}

Keywords: the determining factor for the victory of the deputy regional head. pilkada

\section{AbSTRAK}

$\mathrm{P}_{\mathrm{s}}$ enelitian ini bertujuan untuk mendeskripsikan Faktor-faktor Apa sajakah yang menjadi Penentu kemenangan Wakil Bupati melawan Bupati dalam Pilkada 2015 di Kabupaten Bungo Provinsi Jambi. Penelitian dilakukan melalui pengumpulan data melalui wawancara dan sumber referensi literatur yang didukung terkait dengan menganalisis temuan data. Metode yang digunakan adalah Deskriptif Kualitatif. Dalam penelitian ini peneliti terlibat langsung 
dalam menggali informasi. Secara deduktif, penulis menggunakan teori Peter Schroder (2010) sebagai pisau analisis untuk mendeskripsikan faktor kemenangan Wakil Bupati Melawan Bupati dalam Pilkada 2015.

Hasil penelitian menunjukkan Wakil Bupati Bungo memiliki sejumlah kelebihan dalam faktor internal yang mampu dimanfaatkan dalam Pemilihan Kepala Daerah 2015 untuk menarik simpatik para pemilih. Adanya kelebihan dari kekuatan a). Profil pasangan calon yang berdasarkan Basis wilayah dan identitas suku, b). Individu yang religius, 3). Program yang menarik, 4). Kinerja teruji, 5). Kompetensi berdasarkan pendidikan, serta 5). Sumber daya kekuatan tim sukses yang mengakar sampai ke Desa-desa membuat Wakil Bupati meraih Kemenangan dalam Pilkada. Kemudian beberapa strategi yang digunakan berdasarkan analisis: 1. Pemilihan tim sukses, langkah menentukan pemilihan tim sukses di antaranya, yaitu a).Pendekatan sebelum pilkada,b). Memperluas pergaulan, c). Karakter loyal, d). Pembentukan tim sampai ke pelosok daerah, e). Komunikasi terhadap tim sukses, 2. Kemampuan pengolahan logistik dari Calon Kandidat untuk dapat menggunakan sumber daya finansial secara tepat, 3. Pemilihan profil kandidat dan kewilayahan, penyebaran suara yang tidak terfokus pada satu titik saja, serta 4.Perumusan Program yang menarik hati masyarakat berdasarkan dari permasalahan di lapangan yang sesuai dengan persebaran penduduk terbanyak.

Kata kunci: faktor penentu kemenanga,n Wakil Kepala Daerah. Pilkada

\section{PENDAHULUAN}

$\mathrm{D}$ alam pola kepemimpinan satu paket, hubungan harmonisasi antara Bupati dan Wakil Bupati sangat menentukan keberhasilan efektivitas pemerintahan daerah. Namun, dalam perangkat hukum yang mengatur mengenai kewenangan Bupati dan Wakil Bupati masih terdapat perbedaan yang jauh, hal yang masih sangat kurang dirasakan, sehingga dalam perjalanan birokrasinya timbul anggapan bahwa Wakil Bupati hanya sebatas ban serap bagi jabatan Kepala Daerah. Asumsi yang sepele namun memberikan dampak luar biasa pada jalannya roda pemerintahan.

Fenomena pecah kongsi tersebut terjadi Di Kabupaten Bungo provinsi jambi pada Pemilihan Kepala Daerah secara langsung pada tahun 2015 yang menyisakan beberapa peristiwa yang sangat menarik sehingga, hal tersebut melibatkan Wakil Bupati dan Bupati dalam memperebutkan kursi nomor satu di Kabupaten Bungo secara berlawanan untuk memangku jabatan sebagai Kepala Daerah. Rekapitulasi suara menunjukkan dominannya kemenangan dari H. Mashuri dan Safrudin Dwi Afriyanto memperoleh suara sebanyak 96.712 suara atau \%59,08 hal tersebut sangat berbeda jauh terhadap lawannya H. Sudirman Zaini dan Apriyansah yang memperoleh suara sebanyak 66.971 suara atau $40,92 \%$ dari total jumlah surat suara sah sebanyak 163.683 surat suara sah, jarak selisih suara cukup lumayan jauh perbandingannya sebesar 29.162 suara atau $19 \%$.

\section{METODE PENELITIAN}

Metode Penelitian yang digunakan adalah metode penelitian kualitatif Menurut Effendy (2010:117) bahwa "penelitian kualitatif adalah penelitian yang menjelaskan dan menganalisis perilaku manusia secara individual dan kelompok prinsip atau kepercayaan, pemahaman atau pemikiran, dan persepsi atau tanggapan dengan teknik cara menentukan informan, yaitu Key Person dan teknik pengumpulan data dengan menggunakan teknik wawancara, dan dokumentasi dengan teknik analisis data dengan reduksi data, displai data dan Conclusion Drawing/verification.

\section{KAJIAN PUSTAKA}

Dalam penelitian ini peneliti menggunakan teori Faktor Fakta Kandidat 
menurut Peter Shcroder (2010) dengan enam variabel, yaitu Produk, Multiplikator, Sumber daya, Kepemimpinan, Komunikasi terhadap pemilih, dan Sasaran-sasaran agenda rahasia. Dalam penelitian ini juga menggunakan teori strategi SWOT (strength, waekness, opportunities and threats).

\section{HASIL DAN PEMBAHASAN}

Faktor-faktor Penentu Kemenangan Wakil Bupati melawan Bupati dalam Pilkada 2015 di Kab Bungo Provinsi Jambi

\section{Produk}

\section{a. Profil}

Profil kandidat yang menjadi keunggulan H. Mashuri dan Apri adalah kewilayahan yang menjadi basis terkhusus dari Calon Wakil Bupati yang berasal dari suku tertentu, yaitu Suku Jawa, serta riwayat pendidikan mereka dan pengalaman organisasi yang sudah mereka jalani, di tambah pada sebelumnya bahwa $\mathrm{H}$. Mashuri diketahui sebagai Wakil Bupati Bungo, sehingga dengan kekuatan Profil tersebut masyarakat secara luas mengenal kedua Pasangan Calon tersebut sejak lama.

\section{b. Individu}

Nilai-nilai Individu menjadi penting sebagai modal kepercayaan masyarakat terhadap kandidat dalam memilih, semakin baik nilai yang dimiliki seseorang maka tidak menutup kemungkinan semakin besar pula kepercayaan pemilih terhadap kandidat dalam pelaksanaan Pilkada sehingga apa yang telah dilakukan Mashuri dalam rutinitas Kegiatan keagamaan secara konsisten di tengah-tengah masyarakat menjadikan nilai plus bagi beliau yang di kenal oleh masyarakat dan tim sebagai pribadi yang memiliki nilai-nilai spiritual keagamaan yang kuat berdampak pada kepercayaan yang di berikan untuk dapat menjalankan amanah sebagai Kepala Daerah dengan Visi, Misi, dan Programnya untuk membangun Kabupaten Bungo yang maju dan sejahtera.

\section{c. Program}

Kemenangan telak yang didapatkan atas keterpilihan pasangan $\mathrm{H}$. Mashuri \& Safrudin Dwi Apriyanto berdasarkan dari data memang berasal dari sejumlah Desa-desa yang ada di Kabupaten Bungo, program yang di tawarkan Mashuri berupa Gerakan Dusun Membangun sebesar Rp250 juta mampu menarik antusias dari masyarakat desa untuk memilih, tentu hal tersebut memperlihatkan betapa besarnya Antusias masyarakat berharap akan terwujudnya program-program yang telah di canangkan sebagai solusi dari permasalahan yang mereka hadapi.

\section{d. Kompetensi}

Kemampuan Mashuri dalam pengelolaan pemerintahan memang sudah diketahui oleh masyarakat terutama para ASN di Lingkungan Pemda Kab. Bungo dengan pengalaman nya sebagai seorang Birokrat dari tahun 1998-2010 teruji dengan beberapa jabatan yang di embannya selama menjadi PNS aktif dan juga beliau merupakan Wakil Kepala Daerah Periode 2011-2016. Keuntungan pengalaman dan Jabatan tersebut tentu bukti dari wawasan beliau yang memiliki kemampuan dalam mengelola Pemerintahan dan sekarang sejak pertama kali nya Bungo mendapatkan penghargaan WTP pada tahun 2018 https://makalamnews.com/beritaselengkapnya/bangga-pertama-kalibungo-raih-wtp-dari-bpk/ (di akses pada 26 Juni 2020)

\section{e. Kinerja}

Sebelum menduduki kursi Bupati sejak 2016 lalu, Mashuri pernah menjadi PNS 
pada Dinas Pertanian Tanaman Pangan dan Hortikultura Kabupaten Bungo Tebo pada 1998. Dia pun pernah menjabat sebagai Kasubbid Ekonomi dan Perumusan pada Dinas Pertanian Tanaman Pangan dan Hortikultura Kabupaten Bungo Tebo pada 1999-2001, Kasubbid Evaluasi dan Pengendalian pada Bappeda Kabupaten Bungo pada 2001-2004, dan Kasubbag Pengendalian Program pada Sekretariat Daerah Kabupaten Bungo pada 20042006. Mashuri juga pernah menjabat sebagai Kasubbag Penyusunan Program pada Sekretariat Daerah Kabupaten Bungo pada 2006-2008, Kabid Pengelolaan Aset pada Dinas Pendapatan Pengelolaan Keuangan Daerah dan Aset Kabupaten Bungo pada 2008-2009, dan Kabag Perlengkapan pada Sekretariat Daerah Kabupaten Bungo 2009-2010. Mashuri kemudian terjun ke dunia politik dan duduksebagai Wakil Bupati Bungo periode 2011-2016 mendampingi Sudirman Zaini.

\section{Multiplikator, aliansi, dalam konteks komunikasi politik, multiplikator sama dengan "multiply}

a. Pengganda atau penyebar sebuah pesan politik

Mashuri menegaskan bahwa, cara yang paling efektif dalam menyampaikan pesan-pesan politik atau komunikasi terhadap masyarakat adalah dengan cara menemui langsung, hal ini dapat di dengar oleh masyarakat dengan tatap muka, tentu hal ini akan sangat berdampak pada kandidat, setidaknya masyarakat akan merasa diperhatikan secara langsung oleh kandidat, serta di ingat oleh masyarakat, apalagi $\mathrm{H}$. Mashuri merupakan Wakil Bupati yang menjabat pada periode sebelumnya.

\section{b. Aliansi}

Adapun memang partai koalisi yang bergabung dengan pasangan $\mathrm{H}$. Mashuri dan Safrudin Dwi Apriyanto adalah sebagai berikut. Partai pendukung: PBB, PKS, PKPI, Partai NasDem, PAN. Jika dilihat dari kepemilikan kursi di parlemen dalam DPRD, memang hanya PAN dan PKS yang sama-sama memiliki 3 perwakilan anggota di Kursi Parlemen selanjutnya partai Nasdem yang baru pada waktu mendapat 2 kursi, serta PBB, dan PKPI masing-masing hanya 1 Kursi saja. Hal ini menunjukkan kekuatan $\mathrm{H}$. Mashuri di Parlemen hanya memiliki 10 Kursi saja, tentu ini masih dikategorikan lemah dan sangat sedikit dari jumlah kursi yang ada.

\section{Sumber Daya}

a. Sumber daya Manusia

Kaum militantes, pejuang partai, setiap saat menjalani tugas partai

Adapun sumber daya manusia yang dimiliki Mashuri adalah dari koalisi partai yang tergabung dalam tim Kampanye pemenangan calon Kepala Daerah dari setiap anggota-anggota partai PKS, PAN, PKPI, PBB, dan Nasdem yang berjumlah sebanyak 360 orang terdiri dari:

- Kaum afiliados, anggota yang sewaktu-waktu bersedia melakukan sesuatu demi partai.

- Amunisi dari keluarga, kerabat, dan organisasi sayap memberikan dukungan yang dapat membantu memudahkan pasangan kandidat bekerja selama masa-masa Pilkada, semua dikerahkan untuk bersinergi" dan tahapan pilkada yang telah di tetapkan dengan kesukarelaan mereka atas dasar kedekatan emosional dalam keluarga dan tubuh partai yang dijalani di bawah satu komando.

- Kaum coreligionarios, pemilih tetap

Sesuai dengan basis wilayah kandidat faktor kesukuan kandidat 
dan jaringan yang dimiliki membuat optimis dan mendorong mereka untuk memilih kandidat sebagai pemilih tetap, karena pada titik massa tersebut masih terbilang masyarakat dengan paham politik kedaerahan memilih sesuai dengan wilayah dan kesukuan, dan masyarakat lebih mengutamakan kedekatan emosional".

\section{b. Sumber daya keuangan}

Sumber dana Mashuri dan Apri berasal dari sumbangan Masyarakat yang terdiri dari perseorangan serta kedua Pasangan Calon secara sah yang telah di audit dan di serahkan ke KPUD Bungo, dukungan dana tersebut memberikan kemudahan kepada tim Mashuri dalam melaksanakan tahapan Pilkada 2015 Bungo yang di gunakan sesuai peraturan KPU serta, dalam tim Pilkada dari H. Mashuri dan Apri taat dan patuh terhadap ketentuan yang berlaku dengan penggunaan dana yang sudah ditentukan dari aturan yang berlaku. Mereka melakukan proses tersebut sesuai dengan SOP yang sudah di tetapkan KPU, yaitu berdasarkan dari PKPU Nomor 8 tahun 2015 tentang Dana Kampanye.

\section{c. Sumber daya Organisasi}

Tentu solidnya tim akan berdampak besar terhadap jalannya Pilkada bagi kandidat itu sendiri. Krusialnya peran tim sangat berdampak sekali terhadap kemenangan dari Mulai dari memperkenalkan pasangan calon, Kampanye, memberi pengetahuan kepada masyarakat sampai kepada mengawal suara sah di hari pencoblosan menjadi tugas dari tim sukses. Adapun sumber daya terdiri dari 141 koordinator per dusun, 17 koordinator per kecamatan dan 360 orang secara struktural.

\section{Kepemimpinan}

\section{a. Kebijaksanaan}

Peneliti menemukan data dokumentasi berupa arsip yang dikutip dari NMC Berita mengenai kejadian penolakan masyarakat tentang izin Alfamart oleh Pemkab Bungo, di dalam hal tersebut Wakil Bupati H Mashuri ketika dikonfirmasi menuturkan belum tahu banyak tentang izin Alfa Mart, namun ia ditelepon warga pasar terkait penolakan dengan membubuhkan tanda tangan di atas kain putih sepanjang 15 meter. "Ia saya ditelepon masyarakat bahwa adanya penolakan," ucap H Mashuri. Menurutnya itu bisa menjadi pertimbangan pemerintah dalam pemberian izin Alfamart, ia menegaskan kalau hal tersebut bisa menjadi persoalan di masyarakat lebih baik tidak sama sekali.

\section{b. Kejujuran}

Mengabdi menjadi PNS dari tahun 1998-2010 dan 5 Tahun menjadi wakil bupati tanpa adanya masalah dalam pemerintahan maupun pribadi terkait dengan penggunaan kewenangan dan anggaran, kemudian Di tambah lagi dengan bukti di pemerintahan beliau mendapat penghargaan WTP yang sudah beberapa tahun berturut-turut dari tahun 2017 sampai sekarang, ini menunjukkan komitmen diri mashuri ini bersih".

\section{c. Kerendahan hati}

Seorang pemimpin yang bersedia dan tidak gengsi turun ke bawah bersama orang bawahannya untuk melakukan apa yang harus dilakukan, Dia tidak menempatkan diri sebagai superior tetapi sebagai seorang pembelajar kehidupan. sebab pemimpin harus bersedia mengoreksi dirinya sendiri.

\section{d. Keberanian}

Mashuri mengungkapkan kisah menarik dari pengunduran dirinya,Diketahui 
bahwa ketika hendak maju mencalonkan Kepala Daerah sebagai Bupati, Mashuri mengajukan pengunduran dirinya langsung kepada Bupati aktif pada waktu itu, padahal masa pengabdiannya masih memiliki sekitar 16 tahun, jumlah tersebut belum termasuk jika pengajuan penambahan usia masa pensiun disahkan selama dua tahun. Keputusan itu beliau ambil demi membangun Bungo lebih maju dan sejahtera berdasarkan dengan kebutuhan nyata masyarakat Bungo.

\section{e. Ketegasan}

Usia yang masih tergolong Muda sebagai calon Kepala Daerah tentu menjadi nilai yang berbeda di mata masyarakat akan pendiskripsian karakter kepribadian yang tersematkan secara tidak langsung pada diri Mashuri. "Tegas menjadi salah satu Jargon pada Pilkada 2015, dengan ketegasan tentu kita dapat menentukan kebijakan serta menindak sesuatu yang tak sesuai aturan semua harus berjalan dengan ketentuan hukum yang berlaku".

\section{f. Komunikasi terhadap pemilih}

Selama menjadi Wakil Bupati di tahun 2011, banyak kegiatan yang melibatkan masyarakat, hal tersebut harus di pupuk dengan baik, menjaga komunikasi di lapangan, dan menghampiri mereka, terkadang mereka segan, tetapi harus jemput bola, salah satu yang menjadi tugas memang harus melayani mereka dengan baik. menjaga dengan saling silaturahmi, diskusi, kalau tidak ada kegiatan kumpul-kumpul sambil minum, dan makan di warung".

g. Sasaran-sasaran, selain visi dan misi, semisal agenda terselubung atau rahasia

Kemenangan tersebut sudah disahkan oleh KPUD Kab. Bungo dalam SK Penetapan Keputusan Komisi Pemilihan Umum Kabupaten Bungo Nomor 350/
Kpts/KPU.Bgo/Tahun 2015 tentang Hasil Penetapan Rekapitulasi Hasil Perolehan Perhitungan Suara dan Hasil Pemilihan Bupati dan Wakil Bupati Bungo tahun 2015.

\section{Faktor Menjadi Kendala}

a. Kampanye Hitam

Berdasarkan laporan yang di buat oleh permohonan gugatan yang dilayangkan oleh Pihak lawan kepada MK yang terdapat beberapa poin mengenai laporan tersebut di antaranya sebagai berikut.

1. Puluhan ribu pemilih tidak mendapatkan (undangan pemilih)

2. Meluasnya praktik politik uang

3. Adanya keterlibatan Pegawai Negeri Sipil

4. Panwaslu Kabupaten Bungo beserta jajarannya membiarkan terjadinya pelanggaran

Berdasarkan surat keputusan dari MK NOMOR 90/PHP.BUP-XIV/2016 bahwa laporan tergugat tidak dapat di terima karena tidak terbukti melakukan pelanggaran yang di maksud.

b. Kesulitan bersosialisasi di basis lawan

Diketahui bahwa Desa Kuamangkuning dan Desa Kotojayo sama-sama berada di dalam kecamatan Pelepat ilir yang merupakan tanah kelahiran dari Sudirman Zaini yang mana kecamatan Pelepat Ilir di dominasi oleh warga transmigrasi dari jawa yang merupakan daerah asal dari Apri yang merupakan pasangan dari Mashuri. Pada akhirnya memang di daerah Dusun Kotojayo tersebut dimenangi oleh Sudirman Zaini dengan telak sebagai daerah basis nya.

c. Masih kurangnya Kesadaran Masyarakat terhadap pelaksanaan Pilkada

Masih kurangnya kesadaran politik masyarakat Kabupaten Bungo dalam 
ikut serta pelaksanaan Pemilihan Kepala Daerahpadatahun2015 sebanyak71.137 orang atau 29,8\% tidak menggunakan suaranya. Tentu itu menunjukkan bahwa kesadaran masyarakat memang masih terdapat beberapa yang kurang dalam pelaksanaan Pilkada 2015. Padahal sudah di lakukan berbagai macam kegiatan sosialisasi dan persiapan dalam pelaksanaannya,

d. Kesulitan akses wilayah yang cukup luas Seperti diketahui berdasarkan dari data Bungo dalam Angka 2018 bahwa Secara Administrasi, Luas Kabupaten Bungo adalah $4.659 \mathrm{~km} 2$ yang terdiri dari 17 kecamatan 141 dusun dan 12 kelurahan. Luasan ini setara dengan 8,72 persen luas wilayah Provinsi Jambi. Luas wilayah Provinsi Jambi tercatat $53.435,92 \mathrm{Km} 2$ yang terbagi atas luas daratan 48.989,98 $\mathrm{km} 2$ dan luas lautan $4.445,94 \mathrm{Km} 2$ serta dengan panjang garis pantai $223,025 \mathrm{~km}$.

\section{Strategi meraih kemenangan dalam Pemilihan Kepala Daerah}

Adapun strategi yang digunakan Wakil Bupati dalam kemenangan Pilkada 2015 Kabupaten Bungo berdasarkan analisis dan fakta di lapangan yang diperoleh

1. Strategi dalam pemilihan team sukses

2. Kemampuan pengolahan logistik

3. Profil kandidat dan kewilayahan

4. Perumusan program-program

\section{SIMPULAN}

Berdasarkan hasil penelitian dan pembahasan, maka faktor-faktor penentu kemenangan dapat peneliti simpulkan sebagai berikut.

\section{Produk}

a) Secara aspek Profil kandidat menentukan pasangan bukan hanya saja berdasarkan dengan karakteristik akan tetapi berdasarkan identitas tertentu, dan kewilayahan

b) aspek individu, H. Mashuri selama berkarier menjadi birokrat sering mengikuti kegiatan keagamaan di tengah-tengah masyarakat.

c) segi kompetensi tidak diragukan lagi dengan pengalaman pendidikan yang di tempuhnya menjadi Lulusan S-2 Manajemen sampai dengan memiliki pengalaman menjabat Wabup Bungo 2011-2015.

d) Secara Kinerja pernah menduduki jabatan-jabatan strategis selama menjadi PNS hingga menjadi Wabup tahun 2011.

e) Dalam aspek Program melakukan perumusan masalah berdasarkan dengan kebutuhan masyarakat dengan penglibatan tomas, masyarakat, dan menawarkan program Rp250 juta per desa

\section{Aspek Multipikator}

a) penyebaran politik, melalui media massa, door to door, kampanye akbar

b) Aliansi, berkoalisi dalam partai yang berbasis Islam dan hanya memiliki beberapa kursi saja di DPRD

\section{Sumber daya}

a) Sumber daya manusia

Kaum militan, kader partai yang turun langsung ke masyarakat dalam melakukan sosialisasi dan promosi.

Kaum afiliados, terdiri dari keluarga, kerabat, dan sayap partai yang menjadi kekuatan pendukung secara sukarela tanpa paksaan.

Pemilih tetap, terdiri dari keluarga, kerabat, dan basis kewilayahan asal dari pasangan kandidat. 
b) Sumber daya keuangan berasal dari pasangan calon, masyarakat, dan relawan yang dihimpun dan dikelola secara baik sesuai dengan peruntukannya.

c) Sumber daya organisasi,kemampuan mengelola tim sukses yang berasal dari koalisi partai. Dapatmengontrol dan mengendalikan tim-tim yang terbentuk dari atas sampai bawah.

\section{Kepemimpinan}

a) Kebijaksanaan, mengutamakan kepentingan umum di atas kepentingan pribadi yang menjadi tanggung jawabnya.

b) Kejujuran, selama kurun waktu dari tahun 1998-2015 tidak ditemukan permasalahan-permasalahan selama karier.

c) Kerendahan hati, tidak segan-segan untuk turun langsung ke masyarakat dan berbaur bersama dalam kondisi apa pun, baik itu banjir maupun kegiatan keagamaan, dan diskusi.

d) Keberanian, pengambilan keputusan berdasarkan dengan aturan.

e) Ketegasan, usia yang relatif masih muda dengan slogan Tegas, peduli memiliki semangat dan kuat secara fisik.

5. Komunikasi terhadap pemilih yang efektif untuk menanggapi dan menjawab secara langsung maupun tidak langsung keluhan masyarakat dilakukan melalui Media Sosial, diskusi, dan silaturahmi.

6. Agenda rahasia, berjalan sesuai dengan aturan, prosedur yang ditentukan. ditolaknya semua laporan permasalahan-permasalahan selama Pilkada berlangsung oleh MK dan ditetapkan secara sah menjadi Kepala Daerah terpilih

7. Strategi yang digunakan untuk kemenangan:
1. Pemilihan tim sukses merupakan salah satu faktor kemenangan

2. Kemampuan pengolahan logistik

3. Pemilihan profil kandidat dan kewilayahan

4. Perumusan-Perumusan Program dilakukan berdasarkan dengan kebutuhan masyarakat, jumlah penduduk terbanyak, dan permasalahan yang dihadapi dalam wilayah tersebut.

\section{SARAN}

1. Disarankan kepada pasangan kandidat ke depannya yang akan mencalonkan diri untuk dapat:

a) menggunakan dan memanfaatkan media sosial secara masif, kemajuan teknologi sudah menguasai di setiap daerah, segala berita apa pun dari ujung daerah akan tersampaikan dengan cepat dan efesien.

b) Untuk itu diharapkan mengelola sumber daya manusia lebih kompeten untuk dapat menggeraki kegiatan di sosial media. Kemudian,

c) Membuka penggalangan dana seluas-luasnya.

d) Penglibatan masyarakat yang berpengaruh (tokoh, ulama dll) secara luas di antara mereka sebagai tim akan menambah modal suara yang akan didapatkan, karena mereka memiliki pengikut yang setia pada setiap arahan yang mereka perintahkan.

2. Penggunaan strategi dalam penguatan tim sukses sangat menunjang sekali dalam faktor keterpilihan menjadi Kepala Daerah, oleh karena sebaiknya

a) pembekalan yang dilakukan dalam mengikuti tahap pilkada, Kemudian

b) kegiatan pembinaan, pelatihan, maupun pendampingan bagi tim 
sukses yang bekerja secara teknis di lapangan harus juga diadakan secara berkala dalam waktu yang sudah dijadwalkan,

\section{DAFTAR PUSTAKA}

Effendy, Khasan. 2010. Memadukan Metode Kuantitatif dan Kualitatif. Bandung: CV. Indra Prahasta.

Schroder, Peter. 2013, Strategi Politik. Jakarta: friedrich-naumann-stiftung fur die freihet

Peraturan Perundang-undangan

Surat keputusan dari MK NOMOR 90/PHP.BUP$\mathrm{XIV} / 2016$

PKPU Nomor 8 tahun 2015 tentang Dana Kampanye.
Keputusan Komisi Pemilihan Umum Kabupaten Bungo Nomor 350/Kpts/KPU.Bgo/ Tahun 2015 tentang Hasil Penetapan Rekapitulasi Hasil Perolehan Perhitungan Suara dan Hasil Pemilihan Bupati dan Wakil Bupati Bungo tahun 2015.

\section{Situs Internet}

(http://lintasbarat.com/artikel/detail/hamasniat-maju-untuk-menyejahterakanmasyarakat-kab-bungo.html, pada 1 juni 2020)..

(https: / / www.liputan6.com/pilkada/ $\mathrm{read} / 2418580 / 2$-gugatan-sengketapilkada-jambi-ditolak-mk

https:// makalamnews.com/beritaselengkapnya/bangga-pertama-kalibungo-raih-wtp-dari-bpk/ (di akses pada 26 Juni 2020) 